\title{
A Cross-Sectional Study of the Histopathological correlation with serum Level of Carbohydrate Antigen-125 in Different Forms of Ovarian Cancer
}

\author{
Roquiya Begum ${ }^{1}$, Suhail Ahmad ${ }^{2}$, Ram Binay Sinha ${ }^{3}$, Farhan Usmani ${ }^{4}$ \\ ${ }^{1}$ Tutor, Department Of Biochemistry, Patna Medical College, Patna, ${ }^{2}$ Associate Professor, Department Of Pharmacology, Lord Buddha Koshi Medical College \\ Saharsa Bihar, ${ }^{3}$ Professor Department of Biochemistry, Patna Medical College, Patna, ${ }^{4}$ Associate Professor ,Department Of Biochemistry ,Patna Medical College, \\ Patna.
}

\section{Abstract}

Background: Ovarian cancer is a common malignancy of the female reproductive system. Tumor markers serve as tools in the diagnosis of the disease. The aim of the present study was to determine the diagnostic value of sera levels of carbohydrate antigen-125 (CA-125)and correlate its level with the histopathological findings of the ovarian mass specimen. Subjects and Methods: The sera were measured using an electrochemoluminescence technique on 200 individuals (100 patients with ovarian cancer, and 100 patients as control). Results: The results showed that levels of CA-125 in the sera of the malignant ovarian neoplasm were significantly higher than those of the control groups. In the malignant epithelial cancers, the highest rise was seen in serous Cyst adenocarcinoma, metastatic carcinoma and then mucinous cyst adenocarcinoma, respectively. Conclusion: In conclusion, the results showed that the serum level of CA-125 is important indicators in the diagnosis of ovarian cancer despite its limited sensitivity in early stage of disease and its inadequate specificity for malignancy.

Keywords: Ovarian cancer, carcinoma, histo-pathological correlation.

Corresponding Author: Dr. Suhail Ahmad, Associate Professor, Department Of Pharmacology, Lord Buddha Koshi Medical College Saharsa Bihar.

Received: August 2019

Accepted: August 2019

\section{Introduction}

Ovarian cancer is a complex disease that can arise from various molecular problems. This disease is responsible for the most frequent cause of death from gynecological malignancies because high proportion of cases is detected in advanced stage. ovarian cancer is the second leading cancer in women (affecting about $1 / 70)$ and the deadliest (1\% of all women die of it) It is the 5th leading cause of cancer-related deaths in women, causing an estimated 15,000 deaths in $2008{ }^{[1]}$ still there is no technique which can detect ovarian cancer accurately at an early stage. The study of ovarian lump is very important $\&$ challenging because the diagnosis of ovarian cancer is very difficult due to paucity, vagueness and non-specificity of the symptoms it produces. True neoplastic ovarian enlargement is usually silent unless it is very large enough to produce symptoms or complication.

One of the most promising approaches to management of ovarian cancer is early detection. Stage I ovarian cancer can be cured with currently available therapy in more than $90 \%$ of patients. However, fewer than $25 \%$ of ovarian cancers are currently detected in stage I. Despite advances in the management of advanced ovarian cancer, $70 \%$ to $80 \%$ of patients ultimately succumb to disease that is diagnosed in late stages. Detection of a greater fraction of cancers at an early stage might improve clinical outcome. Tumor markers play a vital role in screening and detection of different stages of cancer progression. Most tumor markers are proteins. The development of an ovarian cancer-specific biomarker for the early detection of disease has the capacity to improve the dismal survival rate. ${ }^{[2]}$ Several epitopes on the polymorphic epithelial mucin derived from the MUC1 gene have been identified as targets for a family of tumor marker. Amongst these markers the most extensively researched is CA125. ${ }^{[3]} \mathrm{CA} 125$ is the most frequently used biomarker for ovarian cancer detection. ${ }^{[4]}$ Around $90 \%$ of women with advanced ovarian cancer have elevated levels of CA-125 in their blood serum, making CA-125 a useful tool for detecting ovarian cancer after the onset of symptoms. ${ }^{[5]}$ Monitoring CA-125 blood serum levels is also useful for determining how ovarian cancer is responding to treatment. ${ }^{[6]}$ The aim of this study was to correlate the serum CA 125 level with the histopathological findings of the ovarian mass specimen. The purpose of the study was to find the diagnostic accuracy of CA 125 level by comparing with the final histopathological diagnosis and thus reduce the rate of mortality due to undiagnosed cases of ovarian cancer.

\section{Subjects and Methods}

\section{$\underline{\text { Study Population }}$}


In total, the present study included 200 cases, which were divided into two group. Each group has 100 of cases.

\section{Study Area}

This study was conducted in the Department of Biochemistry\& Pathology, PMCH, Patna, among the patients admitted in the department of Obstetrics \& gynaecology, PMCH, Patna. Ethics Clearance was obtained from the institutional ethics committee. All participants provided informed consent.

\section{Sample Collection}

In total, the present study included 200 cases, which were divided into two group. Each group has 100 of cases. In first group patients were diagnosed with the ovarian cancer, and second one was control groups that were not diagnosed with OC . Selected patients did not receive chemotherapy or hormonal therapy, or a combination thereof for other tumors or serious heart, liver and kidney disease, or diabetes.

Venous blood was collected and the serum was separated for study . Sample can be stored at 2-8 c for 24 hours. For long term storage, sample should be stored at-700 C.

\section{Sample Detection}

The provisional diagnosis of ovarian cancer was done which was then confirmed by FNAC and post hysterectomy histopathalogical examination of the ovarian masses. The test was done by electrochemoluminescence technique with the help ofelecsys CA-125 II imuno assay analyser The Elecsys CA 125 II test is a sandwich immunoassay that is provided for Elecsys immunoassay systems (Boehringer Mannheim 1996).

\section{Data Analysis}

Data are presented as the mean $6 \mathrm{SD}$. Statistical analyses were performed by the Student $t$ test using MS-Excel. A p value $<0.05$ was considered to be statistically significant.

\section{Results}

We studied 200 cases, among them 100 patients of clinically diagnosed ovarian cancer belong to study group I in whom serum CA-125 was done preoperatively. Another 100 patients without any apparent lump belong to study group II. This study shows the relationship of ovary with the site of lesion. It was found that $23 \%$ of all ovarian cancer arose from left ovary, $28 \%$ arose from right ovary and $40 \%$ cases were bilateral.[Ttable 1] This study found that $22 \%$ cases of serous cystadenocarcinoma were bilateral where as $6 \%$ \& $8 \%$ cases of mucinous cystadenocarcinoma and endometroid adenocarcinoma respectively were bilateral. Both cases of metastatic tumors were bilateral. Dysgerminoma were mostly unilateral. [Table 2]In our study, Serous cystadenocarcinoma occurred mostly between 41-50 years of age group (26\%). Mucinous Cystadenocarcinoma \& Endometroid carcinoma were also common in same age group (i.e. $41-50$ years) having $8 \%$ \& $16 \%$ respectively. Only $2 \%$ cases of serous cystadenocarcinoma were seen in the age group of 21-30 years. The most common age group of ovarian cancer of epithelial origin is between 41-50 years of age comprising $53 \%$ of cases. The second most common group is 31-40 years of age comprising $23 \%$ of cases and 51-60 years age group consist of $14 \%$ of cases.[Table 3] In the present study Surface Epithelial Tumors were most common ovarian cancer consisting of $92 \%$ of cases. This occurred mostly between $41-50$ years of age group (53\%). Germ cell tumors mostly occurred in the younger age group. Metastatic tumors were most common in older age group.[Table4] We studied that all ovarian cancers show higher increase in serum CA-125 level exceeding > 100 $\mathrm{U} / \mathrm{ml}$ except in cases of Clear cell carcinoma(usual level is $<100 \mathrm{U} / \mathrm{ml}$ ). The mean serum CA-125 levels were highest in serous cyst adeno carcinoma \& Metastatic carcinoma $916.00 \& 919.00(\mathrm{U} / \mathrm{ml})$ respectively.[Table 5] We found that most of the cases of Serous cystadenocarcinoma, Endometroid adenocarcinoma, Mucinous cystadenocarcinoma and Metastatic carcinoma had very high values i.e. > $200 \mathrm{U} / \mathrm{ml}$. The serum CA-125 level of Clear cell carcinoma was found to be on 'the lower side i.e. $<65 \mathrm{U} / \mathrm{ml}$. In most cases of Granulosa cell tumor and Dysgerminoma, the rise is in moderate level i.e. between 66 \& $200 \mathrm{U} / \mathrm{ml}$.[Table 6].

Table 1: showing site of lesion of ovarian cancer.

\begin{tabular}{|c|c|c|c|}
\hline No of cases & $\begin{array}{l}\text { Involvement } \\
\text { of left ovary } \\
(\boldsymbol{\%})\end{array}$ & $\begin{array}{l}\text { Involvement } \\
\text { of right ovary } \\
(\boldsymbol{\%})\end{array}$ & $\begin{array}{l}\text { Involvement } \\
\text { of both } \\
\text { ovaries (\%) }\end{array}$ \\
\hline 100 & $32(\%)$ & $28(\%)$ & $40(\%)$ \\
\hline
\end{tabular}

Table 2: Showing distribution of malignant ovarian tumors in one or both ovaries (laterality)

\begin{tabular}{|l|c|c|c|}
\hline $\begin{array}{l}\text { Types of ovarian } \\
\text { cancer }\end{array}$ & $\begin{array}{l}\text { Bilateral(\%a } \\
\text { ge) }\end{array}$ & $\begin{array}{l}\text { Unilateral(\%a } \\
\text { ge) }\end{array}$ & $\begin{array}{l}\text { Total(\%ag } \\
\text { e) }\end{array}$ \\
\hline $\begin{array}{l}\text { Serous } \\
\text { cystadenocarcinoma }\end{array}$ & 22 & 26 & 48 \\
\hline $\begin{array}{l}\text { Mucinous } \\
\text { cystadenocarcinoma }\end{array}$ & 6 & 8 & 14 \\
\hline $\begin{array}{l}\text { Endometroid } \\
\text { adenocarcinoma }\end{array}$ & 8 & 16 & 24 \\
\hline $\begin{array}{l}\text { Undifferentiated } \\
\text { carcinoma }\end{array}$ & 1 & 3 & 4 \\
\hline Clear cell carcinoma & 0 & 2 & 2 \\
\hline $\begin{array}{l}\text { Granulosa cell } \\
\text { carcinoma }\end{array}$ & 0 & 3 & 2 \\
\hline Dysgerminoma & 1 & 0 & 2 \\
\hline $\begin{array}{l}\text { Metastatic(Krukenber } \\
\text { g) }\end{array}$ & 2 & & \\
\hline
\end{tabular}

Table 3: Showing age incidence of malignant ovarian tumors of epithelial origin

\begin{tabular}{|l|l|l|l|l|l|}
\hline $\begin{array}{l}\text { Age } \\
\text { group } \\
\text { (years }\end{array}$ & $\begin{array}{l}\text { Ser } \\
\text { ous } \\
\text { Cys }\end{array}$ & $\begin{array}{l}\text { Mucinous } \\
\text { Cystadenoca } \\
\text { rcinoma }\end{array}$ & $\begin{array}{l}\text { Endom } \\
\text { etroid } \\
\text { carcino } \\
\text { ma }\end{array}$ & $\begin{array}{l}\text { Undiffere } \\
\text { ntiated } \\
\text { carcinom } \\
\text { no }\end{array}$ & $\begin{array}{l}\text { Clear cell } \\
\text { adenocar } \\
\text { cinoma }\end{array}$ \\
& $\begin{array}{l}\text { noma } \\
\text { carc } \\
\text { ino } \\
\text { ma }\end{array}$ & & & & \\
& & & & \\
& & & \\
\hline
\end{tabular}




\begin{tabular}{|l|r|c|c|c|c|}
\hline $0-10$ & - & - & - & - & - \\
\hline $11-20$ & - & - & - & - & - \\
\hline $21-30$ & 2 & - & - & - & - \\
\hline $31-40$ & 14 & 4 & 4 & 1 & - \\
\hline $41-50$ & 26 & 8 & 16 & 2 & 1 \\
\hline $51-60$ & 6 & 2 & 4 & 1 & 1 \\
\hline $\begin{array}{l}61 \& \\
\text { above }\end{array}$ & 0 & 0 & 0 & 0 & 0 \\
\hline
\end{tabular}

Table 4: Showing frequency of individual malignant ovarian tumors in different age group

\begin{tabular}{|l|c|c|c|c|c|}
\hline $\begin{array}{l}\text { Age group } \\
\text { (years) }\end{array}$ & $\begin{array}{l}\text { Surface } \\
\text { Epithelial } \\
\text { Tumors }\end{array}$ & $\begin{array}{l}\text { Germ } \\
\text { Cell } \\
\text { Tumors }\end{array}$ & $\begin{array}{l}\text { Sex- } \\
\text { Cord } \\
\text { Stromal } \\
\text { Tumors }\end{array}$ & $\begin{array}{l}\text { Metastatic } \\
\text { Tumors }\end{array}$ & Total \\
\hline $0-20$ & 0 & 2 & - & - & 2 \\
\hline $21-30$ & 2 & 2 & - & - & 4 \\
\hline $31-40$ & 23 & - & - & - & 23 \\
\hline $41-50$ & 53 & - & 2 & 1 & 56 \\
\hline $51-60$ & 14 & - & - & 1 & 15 \\
\hline $61 \&$ above & 0 & - & - & - & 0 \\
\hline Total(\%age) & 92 & 4 & 2 & 2 & 100 \\
\hline
\end{tabular}

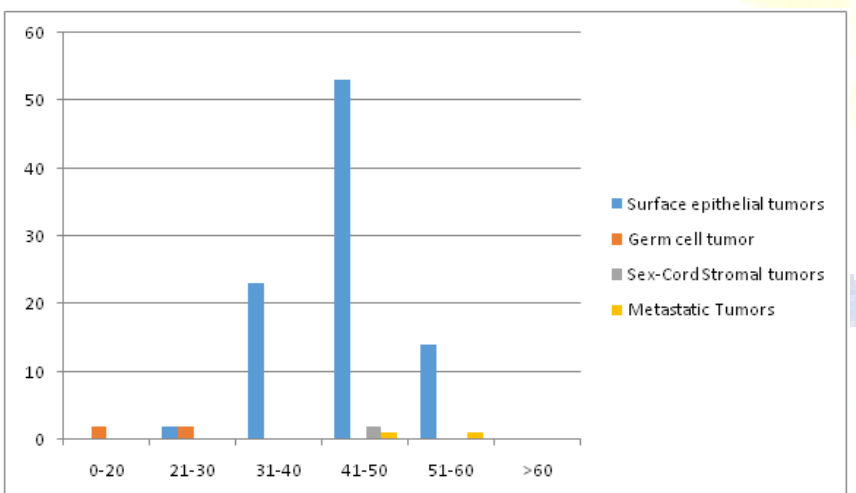

Chart 1: Showing frequency of individual malignant ovarian tumors in different age group

Table 5: Showing mean serum CA-125 levels in the histologically diagnosed types of ovarian cancer

\begin{tabular}{|l|c|c|}
\hline Histological types & No of cases & $\begin{array}{c}\text { Mean level of } \\
\text { CA-125(U/ml) }\end{array}$ \\
\hline 1.Epithelial tumors: & 92 & 751.88 \\
A. Serous cystadenocarcinoma & 48 & 916.00 \\
B. Mucinous cystadenocarcinoma & 14 & 432.21 \\
C. Endometroid adenocarcinoma & 24 & 668.00 \\
D. Undifferentiated carcinoma & 04 & 700.00 \\
E. Clear cell carcinoma & 02 & 60.00 \\
& & \\
\hline 2.Sex cord/ stromal tumors: & 02 & 103.50 \\
A. Granulosa cell tumors & 04 & 231.00 \\
\hline 3.Germ cell tumors: & 02 & 919.00 \\
A. Dysgerminoma & \multicolumn{2}{|l}{} \\
\hline 4.Metastatic carcinoma: & \multicolumn{2}{|l}{} \\
\hline
\end{tabular}

Table 5: Showing malignant histological group of patients with serum CA-125 levels in 4 different ranges

\begin{tabular}{|c|c|c|c|c|}
\hline $\begin{array}{l}\text { Histological types of } \\
\text { ovarian cancer. }\end{array}$ & $\begin{array}{l}\text { No of } \\
\text { cases } \\
\text { with } \\
\text { serum } \\
\text { CA- } \\
125 \\
\text { level < } \\
35 \\
\text { U/ml. }\end{array}$ & $\begin{array}{l}\text { No of } \\
\text { cases } \\
\text { with } \\
\text { serum } \\
\text { CA-125 } \\
\text { level } \\
\text { between } \\
35 \& 65 \\
\text { U/ml. }\end{array}$ & $\begin{array}{l}\text { No of } \\
\text { cases with } \\
\text { serum } \\
\text { CA-125 } \\
\text { level } \\
\text { between } \\
66 \& 200 \\
\text { U/ml. }\end{array}$ & 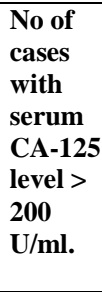 \\
\hline Total No. of cases. & 0 & 3 & 9 & 88 \\
\hline \multicolumn{5}{|l|}{ 1.Epithelial tumors: } \\
\hline $\begin{array}{l}\text { A. Serous } \\
\text { cystadenocarcinoma }\end{array}$ & 0 & 0 & 1 & 47 \\
\hline $\begin{array}{l}\text { B. Mucinous } \\
\text { cystadenocarcinoma }\end{array}$ & 0 & 0 & 2 & 12 \\
\hline $\begin{array}{l}\text { C. Endometroid } \\
\text { adenocarcinoma }\end{array}$ & 0 & 0 & 1 & 23 \\
\hline $\begin{array}{l}\text { D. Undifferentiated } \\
\text { carcinoma }\end{array}$ & 0 & 0 & 0 & 4 \\
\hline E.Clear cell carcinoma & 0 & 2 & 0 & 0 \\
\hline $\begin{array}{l}\text { 2.Sex cord/ stromal } \\
\text { tumors: } \\
\text { A. Granulosa cell } \\
\text { tumors }\end{array}$ & 0 & 1 & 1 & 0 \\
\hline $\begin{array}{l}\text { 3.Germ cell tumors: } \\
\text { A. Dysgerminoma }\end{array}$ & 0 & 0 & 3 & 1 \\
\hline 4.Metastatic carcinoma: & 0 & 0 & 0 & 2 \\
\hline
\end{tabular}

\section{Discussion}

Tumor markers are key markers in the early diagnosis of cancer. For this reason, various tumor markers are considered a promising diagnostic and prognostic tool for accurately identifying stages of cancer. Various studies showed the use of various tumor markers such as HE4, CA125, CA19-9 and CEA, which were used in OC screening. CA -125 is the most frequently used biomarker for ovarian cancer detection. ${ }^{[4]}$ Around $90 \%$ of women with advanced ovarian cancer have elevated levels of CA-125 in their blood serum, making CA-125 a useful tool for detecting ovarian cancer after the onset of symptoms. ${ }^{[5]}$ Monitoring CA-125 blood serum levels is also useful for determining how ovarian cancer is responding to treatment. ${ }^{[6]}$.In the studies reported here, our main aim was to examine the level of serum tumor biomarkers CA-125 in the ovarian cancer patients.

Among the 100 cases of malignant tumors, it was seen that serum CA- 125 level was found to be above $35 \mathrm{U} / \mathrm{ml}$ in all $(100 \%)$ of the cases. In $97 \%$ cases the level was above 65 $\mathrm{U} / \mathrm{ml}$, of which $88 \%$ cases had level above $200 \mathrm{U} / \mathrm{ml}{ }^{[8]}$ Among the sex cord stromal tumor, Granulosa cell tumor showed a level between 35 to $65 \mathrm{U} / \mathrm{ml}$. Kaushar, Farizan, Ashraf et al (2003) found that CA 125 level were raised in $33 \%$ of the sex cord tumors. Thus, CA-125 may be able to identify those patients with aggressive disease requiring individualized management. Its ultimate value may be in combination with other serum tumor markers to identify women who may require either additional chemotherapy or maintenance therapy and vigilant follow-up. This finding supports the clinical diagnostic value of CA-125 as a robust 
serum tumor marker for OC.

In summary, we have demonstrated changes in the CA-125 level in women diagnosed with histopathologically different ovarian cancer. Patients with ovarian cancer have significantly elevated serological levels of CA-125 directly proportional to the disease stage, grade of the tumors, and residual tumor size. The patients with a higher CA-125 level at diagnosis were more likely to suffered with adenocarcinoma and had a significantly worse overall survival.

\section{Conclusion}

In conclusion, the results showed that the serum level of CA-125 is important indicators in the diagnosis of ovarian cancer despite its limited sensitivity in early stage of disease and its inadequate specificity for malignancy.
1. The Merck Manual for Healthcare Professionals 2008.

2. Tuxen MK et al 1995Taxans in the treatment of ovarian cancer1996 Jul 1;158(27):3951-2.

3. Meyer T, Rustin GJ et al Role of tumor markers in monitoring epithelial ovarian cancer. Br J Cancer. May 2000;82(9):1535-8.

4. Suh KS, Park SW,et al 2010 Ovarian cancer biomarkers for molecular biosensors and translational medicine 2010 Nov;10(8):1069-83. doi: 10.1586/erm.10.87.

5. Gupta D, Lis CG et al 2010 Pretreatment serum albumin as a predictor of cancer survival: a systematic review of the epidemiological literature Nutr 2010;9:69.

6. Bast RC, Klug TL et al Intraperitonialimmunotherapy of human ovarian carcinoma with Corenobacteriumparavum, Cancer research 1983;43(3:) 1395-1401.

7. V.Thakur, A.K. Anand, U.Mukherjee and D. Ghosh et al 2003 DETERMINATION OF CANCER ANTIGEN 125 IN OVARIAN CARCINOMA Indian Journal of Clinical Biochemistry, 2003, 18 (2) 27-33.

8. Chen, Schwartz and Yang (1988) conducted a study on 52 cases of malignant tumor and found that $82 \%$ cases had CA-125 level above $35 \mathrm{U} / \mathrm{ml}, 77 \%$ had level above $65 \mathrm{U} / \mathrm{ml}$ and $65 \%$ had levels above $200 \mathrm{U} / \mathrm{ml})$.

\section{References}

Copyright: () the author(s), 2019. It is an open-access article distributed under the terms of the Creative Commons Attribution License (CC BY 4.0), which permits authors to retain ownership of the copyright for their content, and allow anyone to download, reuse, reprint, modify, distribute and/or copy the content as long as the original authors and source are cited.

How to cite this article: Begum R, Ahmad S, Sinha RB, Usmani F. A Cross-Sectional Study of the Histopathological correlation with serum Level of Carbohydrate Antigen-125 in Different Forms of Ovarian Cancer. Asian J. Med. Res. 2019; 8(3):BC01-BC04.

DOI: dx.doi.org/10.21276/ajmr.2019.8.3.BC1

Source of Support: Nil, Conflict of Interest: None declared. 